\title{
Pengaruh Pengungkapan Corporate Social Responsibility Terhadap Tax Avoidance Dengan Gender Sebagai Variabel Moderasi (Studi Empiris pada Perusahaan Manufaktur yang Terdaftar di Bursa Efek Indonesia Tahun 2016)
}

\author{
Aprilian Kusuma Ningrum ${ }^{1}$, Eny Suprapti ${ }^{2}$, Achmad Syaiful Hidayat Anwar ${ }^{3}$ \\ Prodi Akuntansi FEB Universitas Muhammadiyah Malang
}

\begin{abstract}
This research is aim to provide empirical evidence of the influence of corporate social responsibility (CSR) to tax avoidance by genderas moderating variavble. The sample is listed manufactures corporation in Indonesia Stock Exchange, according to purposive sampling method which produces 65 companies. Observation period is 2016. Independent variable disclosure of CSR is measured by using Global Reporting Initiative (GRI) 63 indicator. Dependent variable tax avoidance is measured by using effective tax rate (ETR). Gender moderating variable is measured by the proportion of the women in company's board of commissioners and board of directors. The data in this research is analized by using SPSS with Moderated Regression Analysis (MRA) method.The result of this research shows that CSR disclosure provides the negative effect totax avoidance. Gender (the proportion of women in company councils) has strengthened the effect of CSR disclosure on tax avoidance practice.
\end{abstract}

Keywords : Corporate Social Responsibility (CSR), Gender, Tax Avoidance

Correspondence to : apriliankusuma@gmail.com, e.suprapti@yahoo.com

\section{PENDAHULUAN / INTRODUCTION}

Selama beberapa dekade terakhir, terdapat beberapa perusahaan yang melakukan CSR sebagai kamuflase untuk mengelabui banyak pihak. Alasan yang paling menonjol adalah sebagai strategi bisnis untuk bertanggung jawab kepada masyarakat agar tidak memprotes dan menolak kehadiran perusahaan yang telah mengeksploitasi alam dan merusak lingkungan. Alasan lain yaitu menghindari pajak. Perusahaan dengan sengaja membuat program dan aktivitas CSR semu serta melakukan markup biaya CSR dalam jumlah besar dengan motif menghindari pajak (tax avoidance). (Kontan.co.id)

Tax avoidance merupakan upaya atau tindakan perusahaan untuk meminimalisir beban pajak penghasilan yang harus di bayarkan oleh perusahaan kepada negara melalui pemerintah secara legal, yaitu dengan memanfaatkan celah-celah hukum perpajakan yang berlaku. Perusahaan melakukan praktik tax avoidance untuk meningkatkan cash flow perusahaan, akan tetapi mengakibatkan tidak tercapainya tujuan negara untuk memaksimalkan penerimaan atau pendapatan negara dari sektor pajak (Putri et al., 2014).

Pada dasarnya perusahaan memiliki kewajiban atas seluruh aktivitasnya kepadastakeholder. Perusahaan harus menjaga hubungan baik dengan stakeholder dan memenuhi harapan-harapan yang di inginkan. Salah satu bentuk pemenuhan hak stakeholder adalah dengan melakukan pembayaran pajak sesuai ketentuan kepada 
pemerintah, sehingga perusahaan dapat dikatakan betanggung jawab terhadap para stakeholder dan akan mendapatkan legitimasi dari masyarakat.

Tanggung jawab sosial atau dapat disebut Corporate Social Responsibility (CSR) merupakan komitmen perseroan atau perusahaan untuk berperan serta dalam pembangunan ekonomi berkelanjutan guna meningkatkan kualitas kehidupan dan lingkungan yang bermanfaat, baik bagi perseroan sendiri, komunitas setempat, maupun masyarakat pada umumnya (Undang-Undang No.40 Tahun 2007 Pasal 1 ayat 3). Di Indonesia pengungkapan CSR merupakan hal yang bersifat voluntary atau tidak wajib dilakukan oleh perusahaan.

Perusahaan melakukan aktivitas CSR sebagai cara memeroleh legitimasi dari masyarakat. CSR dianggap sebagai kepedulian perusahaan dalam menyejahterakan masyarakat dan kelestarian lingkungan (Habibi, 2017). Selain itu, perusahaan melakukan aktivitas CSR untuk memenuhi kewajiban terhadap stakeholdernya.

Hubungan CSR dengan tax avoidance dapat dijelaskan bahwa CSR merupakan bentuk tanggung jawab perusahaan kepada seluruh stakeholder. Pajak merupakan salah satu bentuk tanggung jawab sosial perusahaan kepada stakeholder melalui pemerintah. Dengan demikian, perusahaan yang terlibat penghindaran pajak adalah perusahaan yang tidak bertanggung jawab sosial (Lanis dan Richardson, 2012), sehingga keputusan perusahaan untuk melakukan praktik tax avoidance juga dipengaruhi oleh keputusan melakukan aktivitas CSR (Hidayat et al., 2016).

Hoi et al., (2013) meneliti pada perusahaan Public United State tahun 20032009. Hasilnya, perusahaan dengan pengungkapan CSR yang tidak bertanggung jawab maka perusahaan melakukan praktik tax avoidance secara agresif. Penelitian yang dilakukan oleh Dharma dan Noviari (2017) bertujuan untuk menguji dan memberikan bukti empiris pengaruh corporate social responsibility (CSR) dan capital intensity terhadap tax avoidance. Hasilnya menunjukkan perusahaan yang melakukan aktivitas CSR lebih tinggi, tidak banyak melakukan praktik tax avoidance sebagai bentuk tindakan bertanggung jawab secara sosial.

Pemilihan dan penetapan suatu keputusan bisnis juga diperlukan sumber manusia yang memadai dari pihak-pihak pengambil keputusan dalam hal ini adalah dewan komisaris dan direksi yang merupakan organ perusahaan. Adanya perempuan dalam perusahaan diharapkan dapat memberikan kesempatan yang sama bagi setiap orang dan memberikan keputusan yang tepat dengan risiko yang lebih rendah (Kusumastuti et al., 2006). Perempuan cenderung memiliki sifat kehati-hatian yang tinggi, teliti, dan menghindari risiko.

Penelitian ini merupakan penelitian yang dilakukan dengan landasan belum konklusifnya hasil penelitian sebelumnya, dengan melakukan pengujian kembali pengaruh pengungkapan CSR terhadap tax avoidance dengan menggunakan gender sebagai variabel moderasi.

\section{PERUMUSAN HIPOTESIS}

Pengaruh Corporate Social Responsibility Terhadap Tax Avoidance

Perusahaan melakukan pengungkapan CSR untuk mendapatkan legitimasi positif dari masyarakat guna mempertahankan kelangsungan hidup perusahaan. Perusahaan dituntut untuk mampu melakukan aktivitasnya sesuai dengan nilai dan batasan norma yang berlaku di masyarakat (Pradipta dan Supriyadi, 2015). Perusahaan dengan reputasi yang baik akan mempertahankan reputasinya dengan 
melakukan tanggung jawab atas aktivitasnya dan tidak melakukan praktik tax avoidance (Ratmono dan Sagala, 2014). Hal tersebut menunjukkan, semakin perusahaan melakukan pengungkapan CSR maka semakin rendah tingkat tax avoidance.

Dharma dan Noviari (2017), mengungkapkan perusahaan dengan kegiatan CSR yang bertanggung jawab memiliki kemungkinan lebih rendah untuk terlibat dalam praktik tax avoidance. Hal serupa diungkapkan oleh Hoi et al., (2013) yaitu perusahaan dengan kegiatan CSR yang tidak bertanggung jawab secara sosial memiliki keterlibatan dalam praktik tax avoidance.

\section{$H_{1}$ : Pengungkapan Corporate Social Responsibility berpengaruh negatif terhadap Tax Avoidance \\ $\begin{array}{cccc}\text { Pengaruh } & \text { Gender } & \text { Sebagai } & \text { Variabel } \\ \text { Moderasi } & \text { Pada } & \text { Corporate } & \text { Social }\end{array}$} Responsibility Terhadap Tax Avoidance

Keberadaan perempuan dalam jajaran dewan komisaris dan direksi menandakan perusahaan tidak melakukan diskriminasi bagi setiap orang, sehingga pada akhirnya akan meningkatkan reputasi dan nilai perusahaan (Brammer et al., 2007 dalam Rahindayati, 2015). Keberagaman dalam dewan perusahaan menunjukkan peningkatan representasi pandangan moral dan etika yang akan memicu perusahaan meningkatkan kualitas pembuatan keputusan pengungkapan tanggung jawab sosial perusahaan (Arfken, Bellar dan Helms, 2004; Strandberg, 2005; Mackenzie, 2007 dalam Handajani, 2014).

Bernardi dan Threadgill (2010), mengungkapkan keberadaan dan meningkatnya jumlah wanita sebagai board of director perusahaan berkorelasi kuat dengan meningkatkan perhatian terhadap masalah-masalah etis dan lingkungan. Hal serupa diungkapkan oleh Rahindayati (2015) yaitu perusahaan dengan keterwakilan perempuan dalam dewan perusahaan melakukan pengungkapan informasi CSR secara luas.

\section{$\mathrm{H}_{2}$ : Gender memperlemah pengaruh Corporate Social Responsibility terhadap Tax Avoidance}

\section{METODE PENELITIAN / METHODS}

Penelitian ini merupakan penelitian asosiatif dengan mengambil objek perusahaan manufaktur yang terdaftar di Bursa Efek Indonesia (BEI) tahun 2016. Pengambilan sampel menggunakan metode purporsive. Data yang digunakan dalam penelitian adalah data sekunder berupa laporan tahunan dan laporan keuangan yang diperoleh dari website BEI yaitu www.idx.co.iddan website masingmasing perusahaan dengan teknik dokumentasi.

Definisi operasional dan pengukuran variabel penelitian sebagai berikut :

1. Dependent Variable. Variabel dependen adalah variabel yang dijelaskan oleh variabel independen. Dalam penelitian ini variabel dependen yaitu tax avoidance. Tax avoidance dalam penelitian ini diproksikan menggunakan rasio effective tax rate (ETR) yang digunakan oleh Lanis dan Richardson (2012), dengan rumus sebagai berikut:

$$
E T R=\frac{\text { Beban Pajak Penghasilan }}{\text { Pendapatan sebelum Pajak }}
$$

2. Independent Variable. Variabe Independen adalah variabel yang menjelaskan variabel dependen. Dalam penelitian ini variabel independen yaitu CSR. CSR diukur menggunakan rasio pengungkapan CSR dengan tabel checklist yang mengacu pada Global Reporting Initiative (GRI) G3 sebanyak 79 item. Apabila item $i$ diungkapkan perusahaan maka diberikan nilai 1 dan 0 jika item $i$ tidak diungkapkan pada tabel check list. Adapun rumus CSRI sebagai berikut :

$$
\operatorname{CSRIj}=\frac{\sum X i j}{N j}
$$


CSRIj: Indeks luas pengungkapan tanggung jawab sosial dan lingkungan perusahaan $\mathrm{j}$.

$\sum X i j \quad$ : nilai 1 jika item i diungkapkan; nilai 0 jika item $\mathrm{i}$ tidak diungkapkan.

$\mathrm{Nj}$ : jumlah item untuk perusahan $\mathrm{j}$, $\mathrm{nj} \leq 79$.

3. Moderated Variable. Variabel Moderasi adalah variabel independen yang dapat memperkuat atau memperlemah hubungan antara variabel independen dengan variabel dependen. Dalam penelitian ini variabel moderating yaitu gender yang merupakan proporsi perempuan dalam dewan komisaris dan direksi dibandingkan dengan jumlah keseluruhan anggota dewan komisaris dan direksi.

Analisis data dilakukan dengan tahapan sebagai beriku :

1. Statistic Descriptive. Uji ini dilakukan untuk memberikan gambaran atau deskripsi suatu data dari sampel penelitian yang dilihat dari nilai rata-rata (mean), standar deviasi, maksimum dan minimum.

2. Uji Asumsi Klasik. Dalam uji asumsi klasik terdapat 2 (dua) tahap pengujian, yaitu :

a. Uji Normalitas. Uji ini bertujuan untuk menguji model regresi, apakah terdapat variabel pengganggu atau residual terdistribusi normal. Uji statistik sederhana dapat dilakukan dengan melihat nilai signifikansi SkewnessKurtosis (S-K). Uji $\quad \mathrm{S}-\mathrm{K}$ dapat dikatakan nilai residu terdistribusi normal apabila nilai Zskew dan Zkurt $\leq$ $\pm 1,96$.

b. Uji Heteroskedastisitas. Uji ini dilakukan untuk menguji apakah dalam model regresi terjadi ketidaksamaan varian dari residual suatu pengamatan ke pengamatan yang lain. Dalam penelitian ini digunakan uji Glejser dengan meregresi nilai absolut residual terhadap variabel independen. Jika nilai signifikansi variabel independen $\geq$ 0,05 (probabilitas) maka model regresi tidak terjadi adanya heteroskedastisitas.

3. Uji Hipotesis. Uji ini dilakukan dengan menggunakan metode analisis Moderated Regression Analysis (MRA) atau uji interaksi. Adapun model persamaan pengujian hipotesis, yaitu sebagai berikut :

$$
\begin{gathered}
\mathrm{ETR}=\mathrm{a}+\mathrm{b}_{1} \mathrm{CSR}+\mathrm{b}_{2} \mathrm{GDR}+\mathrm{b}_{3} \\
\mathrm{CSR}^{*} \mathrm{GDR}
\end{gathered}
$$

Dalam uji hipotesis terdapat 3 (tiga) tahap pengujian, yaitu :

a. Koefisien Determinasi $\left(R^{2}\right)$. Uji ini bertujuan untuk mengukur seberapa jauh kemampuan model regresi dalam menerangkan variasi variabel dependen. Nilai koefisien determinasi $\left(\mathrm{R}^{2}\right)$ adalah nol dan satu.

b. Uji Signifikansi Simultan (Uji F). Uji F bertujuan untuk memprediksi model regresi apakah variabel independen dan moderasi secara bersama-sama berpengaruh terhadap variabel dependen. Variabel independen dan moderasi dikatakan secara bersamasama berpengaruh terhadap variabel dependen apabila nilai signifikansi yang dihasilkan lebih kecil dari tingkat signifikansi yang ditentukan, yaitu sebesar $5 \%$ atau 0,05

c. Uji Signifikansi Parameter Individual (Uji t). Uji t bertujuan untuk mengukur masing-masing variabel independen terhadap variabel dependen. Variabel independen dikatakan berpengaruh terhadap variabel dependen apabila nilai signifikansi yang dihasilkan lebih kecil dari tingkat signifikansi yang ditentukan, yaitu sebesar 5\% atau 0,05 . 


\section{HASIL PENELITIAN / RESULTS}

Penelitian ini menggunakan sampel perusahaan go publicsektor manufaktur yang terdaftar di Bursa Efek Indonesia (BEI) tahun 2016. Berdasarkan distribusi pengambilan sampel, maka jumlah sampel dalam penelitian ini adalah sebanyak 65 perusahaan dari total populasi penelitian sebanyak 144 perusahaan. Penelitian ini menggunakan 3 variabel, terdiri dari variabel dependen yaitu tax avoidance, variabel independen berupa corporate social responsibility (CSR), serta variabel moderasi yaitu gender. Penelitian statistik deskriptif dalam penelitian ini berupa nilai minimum, nilai maksimum, nilai rata-rata serta standar deviasi.

Tabel 1. Hasil Analisis Statistik Deskriptif

\begin{tabular}{lccccc}
\hline Variabel & N & Minimum & Maximum & Mean & $\begin{array}{c}\text { Std. } \\
\text { Deviation }\end{array}$ \\
\hline ETR & 65 &, 02 &, 43 &, 2585 &, 08078 \\
CSR & 65 &, 15 &, 62 &, 2954 &, 08516 \\
GDR & 65 &, 00 &, 43 &, 1728 &, 13042 \\
Valid N (listwise) & 65 & & & & \\
\hline
\end{tabular}

Sumber: Data Diolah

Berdasarkan hasil analisis pada tabel 1 menunjukkan bahwa variabel tax avoidance yang diproksikan dengan effective tax rate (ETR) memiliki nilai minimum sebesar 0,02 dan nilai maksimum sebesar 0,43 , sedangkan nilai rata-rata keseluruhan sebesar 0,2585 dengan standar deviasi sebesar 0,08078 yang menunjukkan tingkat variasi sebaran data. Variabel corporate social responsibility yang diproksikan dengan corporate social responsibility index (CSRI) memiliki nilai minimum sebesar 0,15 dan nilai maksimum sebesar 0,62, sedangkan nilai rata-rata keseluruhan sebesar 0,2954 dengan standar deviasi menunjukkan sebaran data sebesar 0,08516. Hasil analisis menunjukkan bahwa indeks CSR yang dilakukan oleh perusahaan manufaktur sebesar 29,54\%. Variabel gender yang diproyeksikan dengan proporsi perempuan dalam dewan perusahaan memiliki nilai minimum sebesar 0,00 dan nilai maksimum sebesar 0,43 , sedangkan nilai rata-rata keseluruhan sebesar 0,1728 dengan standar deviasi sebesar 0,13042. Hasil analisis menunjukkan bahwa proporsi perempuan dalam dewan perusahaan sebesar $17,28 \%$.

Uji asumsi klasik dilakukan dengan 2 tahap, yaitu uji normalitas dan uji heteroskedastisitas. Uji normalitas yang dilakukan menghasilkan nilai $Z_{\text {hitungskewness }}$ dan $Z_{\text {hitungkurtosis dibawah nilai }} Z_{\text {tabel }}$ yaitu $0,309<1,96>1,193$. Hal ini menunjukkan data residual terdistribusi normal. Uji heteroskedastisitas menghasilkan tidak adanya variabel independen yang signifikan secara statistik mempengaruhi variabel dependen. Nilai signifikansi setiap variabel independen menghasilkan nilai di atas probabilitas signifikansi yang telah ditentukan, yaitu sebesar 5\% atau 0,05 . Hal ini berarti dapat dikatakan bahwa model regresi yang digunakan terbebas dari adanya heteroskedastisitas. 
Balance Vol. XV No. 1 | Januari 2018

Tabel 2. Hasil Analisis Uji Koefisien Determinasi $\left(\mathbf{R}^{\mathbf{2}}\right)$

\begin{tabular}{ccccc}
\hline Model & R & R Square & Adjusted R Square & $\begin{array}{c}\text { Std. Error of the } \\
\text { Estimate }\end{array}$ \\
\hline 1 &, $389^{a}$ &, 151 &, 110 &, 07622 \\
\hline
\end{tabular}

Sumber: Data Diolah

Tabel 2 menunjukkan nilai koefisien determinasi dengan parameter Adjusted $R$ Square sebesar 0,110. Hal ini berarti bahwa variabel dependen yaitu tax avoidance dapat dijelaskan sebesar $11 \%$ oleh variabel independen (CSR) dan variabel moderasi (gender). Sedangkan selebihnya 89\% (100\% - 11\%) dapat dijelaskan oleh variabelvariabel lain diluar model regresi.

Tabel 3. Hasil Analisis Uji Signifikansi Simultan (Uji F)

\begin{tabular}{clccccc}
\hline & Model & $\begin{array}{c}\text { Sum of } \\
\text { Squares }\end{array}$ & df & $\begin{array}{c}\text { Mean } \\
\text { Square }\end{array}$ & F & Sig. \\
\hline 1 & Regression &, 063 & 3 &, 021 & 3,628 & ,018 $^{\text {b }}$ \\
& Residual &, 354 & 61 &, 006 & & \\
& Total &, 418 & 64 & & \\
\hline
\end{tabular}

Sumber: Data Diolah

Tabel 3 menunjukkan hasil uji $\mathrm{F}$

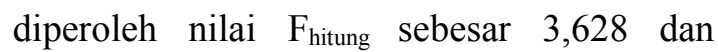
apabila dibandingkan dengan nilai $\mathrm{F}_{\text {tabel }}$ maka diperoleh $F_{\text {hitung }}>F_{\text {tabel }}$ yaitu sebesar 3,628> 3,15. Nilai dari signifikansi sebesar 0,018 lebih kecil dari 0,05 .
Hal ini menunjukkan bahwa model persamaan regresi dapat digunakan untuk memprediksi tax avoidance atau dapat dikatakan bahwa CSR dan gender (GDR) secara bersama-sama berpengaruh terhadap tax avoidance (ETR), sehingga model yang digunakan untuk penelitian layak (fit).

Tabel 4. Hasil Analisis Uji Signifikansi Parameter Individu (Uji t)

\begin{tabular}{|c|c|c|c|c|c|c|}
\hline & \multirow[t]{2}{*}{ Model } & \multicolumn{2}{|c|}{$\begin{array}{c}\text { Unstandardized } \\
\text { Coefficients }\end{array}$} & \multirow{2}{*}{$\begin{array}{c}\begin{array}{c}\text { Standardized } \\
\text { Coefficients }\end{array} \\
\text { Beta }\end{array}$} & \multirow[t]{2}{*}{$\mathbf{t}$} & \multirow[t]{2}{*}{ Sig. } \\
\hline & & B & Std. Error & & & \\
\hline \multirow{4}{*}{1} & (Constant) &, 432 &, 061 & & 7,027 & ,000 \\
\hline & CSR &,- 659 & ,210 &,- 695 & $-3,135$ & ,003 \\
\hline & GDR &,- 480 & ,233 &,- 774 & $-2,055$ &, 044 \\
\hline & CSR.GDR & 1,981 & ,764 & 1,149 & 2,592 & ,012 \\
\hline
\end{tabular}

Sumber: Data Diolah

Tabel 4 menunjukkan nilai signifikansi probabilitas 0,05 dan nilai B (beta) sebesar untuk CSR adalah 0,003 lebih kecil dari 0,659. Hal ini berarti CSR berpengaruh 
negatif terhadap tax avoidance $\left(\mathrm{H}_{1}\right.$ diterima) atau dengan kata lain semakin tinggi perusahaan melakukan pengungkapan CSR maka semakin rendah perusahaan melakukan praktik tax avoidance. Selain itu dapat dilihat pada tabel 1 menunjukkan rata-rata dari variabel CSR sebesar 0,2954 atau sebesar 29,54\%. Perusahaan dengan pengungkapan CSR $>29,54 \%$ sebanyak 35 perusahaan atau sebesar $53,85 \%$ dari total perusahaan dalam penelitian ini yaitu sebesar 65 perusahaan. Dalam indikator pengungkapan CSR (EC1) menyatakan perolehan dan distribusi nilai ekonomi langsung, meliputi pembayaran kepada penyandang dana serta pemerintah, dll. Pernyataan tersebut dapat diproyeksikan sebagai kepatuhan dalam pembayaran pajak. Perusahaan yang melakukan pengungkapan pada indikator EC1 sebanyak 49 perusahaan atau sebesar $75,38 \%$.

Di Indonesia aktivitas CSR merupakan hal yang bersifat voluntary atau tidak wajib dilakukan oleh perusahaan. Hal tersebut dapat dijelaskan dalam Undang-Undang No.40 Tahun 2007 pasal 1 ayat 3 tentang Perseroan Terbatas (PT) menyatakan bahwa tanggung jawab sosial dan lingkungan (CSR) adalah komitmen perseroan/perusahaan untuk beperan serta dalam pembangunan ekonomi berkelanjutan guna meningkatkan kualitas kehidupan dan lingkungan yang bermanfaat, baik bagi perseroan sendiri, komunitas setempat maupun masyarakat pada umumnya. Berdasarkan pengertian tersebut, tanggung jawab sosial dan lingkungan (CSR) merupakan sebuah komitmen atau kesadaran dari perusahaan.

Perusahaan dengan pengungkapan tanggung jawab sosial (CSR) secara sukarela atau atas kesadaran dari organ-organ perusahaan mengintegrasikan perhatian dan transparansi terhadap sosial dan lingkungan ke dalam operasi perusahaan dan interaksi kepada para stakeholder-nya. Jika perusahaan melakukan penghindaran pajak, maka reputasi perusahaan akan rusak dimata masyarakat ataupun stakeholder. Sehingga tingkat aktivitas CSR yang tinggi cenderung semakin tinggi pula sikap tanggung jawab yang dimiliki perusahaan dicerminkan dalam sikap patuhnya dalam membayar beban pajak yang telah ditetapkan atau tidak melakukan penghindaran pajak.

Hasil penelitian ini mendukung teori legitimasi yang menyatakan bahwa perusahaan akan mendapat legitimasi dari masyarakat dengan mengungkapkan aktivitas CSR yang telah dilakukan dan melakukan pembayaran pajak melalui pemerintah dengan jumlah yang telah ditentukan. Hal ini juga mendukung teori stakeholder dimana perusahaan tidak hanya bertanggung jawab terhadap kepentingan dalam perusahaan tetapi juga bertanggung jawab terhadap kepentingan seluruh stakeholder-nya. Perusahaan harus memberikan kontribusi kepada masyarakat melalui aktivitas CSR dan pemerintah melalui pembayaran pajak, sehingga perusahaan dapat bertanggung jawab sosial terhadap seluruh stakeholder.

Hasil penelitian ini mendukung penelitian yang dilakukan oleh Hoi et al. (2013) yang menyatakan bahwa perusahaanperusahaan dengan kegiatan CSR yang tidak bertanggung jawab secara sosial memiliki keterlibatan dalam penghindaran pajak yang lebih tinggi. Hal yang sama diungkapkan oleh Dharma dan Noviari (2017), perusahaan dengan kegiatan CSR yang bertanggung jawab memiliki kemungkinan lebih rendah untuk terlibat dalam kegiatan penghindaran pajak.

Untuk gender nilai signifikansi diperoleh sebesar 0,044 lebih kecil dari probabilitas 0,05 dan nilai B (beta) sebesar 0,480. Hal ini berarti secara parsial gender berpengaruh negatif secara signifikan terhadap tax avoidance. Dengan adanya perempuan dalam dewan perusahaan maka 
perusahaan tidak akan melakukan praktik tax avoidance.

Interaksi antara CSR dan gender (CSR.GDR) menghasilkan nilai signifikansi sebesar 0,012 lebih kecil dari nilai probabilitas 0,05 dan nilai B (beta) sebesar 1,981 , sehingga gender memperkuat pengaruh CSR terhadap tax avoidance $\left(\mathrm{H}_{2}\right.$ ditolak). Hal ini berarti bahwa dengan adanya proporsi perempuan dalam dewan perusahaan (gender) sebagai variabel moderasi dapat memperkuat pengaruh CSR terhadap tax avoidance. Perusahaan yang memiliki dewan komisaris dan direksi perempuan maka perusahaan tersebut melakukan pengungkapan CSR secara bertanggung jawab dan melakukan praktik tax avoidance. Selain itu, analisis data pada Tabel 4.3 menunjukkan rata-rata gender sebesar 0,0527 atau sebesar 5,27\%. Proporsi perempuan dalam dewan perusahaan memiliki nilai yang sangat rendah, sehingga tidak mampu memberikan kontribusi untuk pengambilan keputusan yang tepat dan belum mampu melakukan pengawasan secara optimal untuk mencegah terjadinya tindakan tax avoidance. Perusahaan melakukan aktvitas CSR dan pengungkapan secara luas hanya untuk menutupi atau mengelabui banyak pihak bahwa perusahaan tersebut melakukan praktik tax avoidance.

Penelitian ini tidak mendukung penelitian yang dilakukan oleh Bernardi dan Threadgill (2010) yang menemukan bahwa jumlah anggota dewan perusahaan perempuan berpengaruh pada perilaku sosial perusahaan. Rahindayati mengungkapkan bahwa perusahaan yang memiliki keterwakilan perempuan dalam jajaran dewan komisaris dan dewan direksi dengan presentase tertentu melakukan pengungkapan informasi CSR yang lebih luas.

\section{KESIMPULAN/CONCLUSION}

Hasil pengujian hipotesis pertama ditemukan bahwa corporate social responsibility (CSR) berpengaruh negatif terhadap tax avoidance. Sehingga perusahaan yang melakukan pengungkapan CSR secara luas, maka perusahaan tersebut tidak melakukan praktik tax avoidance. Hasil pengujian hipotesis kedua ditemukan bahwa keberadaan perempuan dalam dewan komisaris dan direksi (gender) dapat memperkuat pengaruh corporate social responsibility (CSR) dengan tax avoidance. Sehingga keberadaan perempuan dalam dewan perusahaan tidak dapat memberikan kontribusi dalam pengambilan keputusan yang

tepatuntukmelakukanpengungkapansecaralua sdan praktiktax avoidance.

\section{KETERBATASAN DAN SARAN}

Penelitian ini berpotensi adanya subjektifitas peneliti saat melakukan checklist terhadap item pengungkapan corporate social responsibility. Untuk meminimalkan adanya subjektifitas, peneliti selanjutnya dapat melakukan checklist secara berulang dan dengan melibatkan tim.

\section{DAFTAR PUSTAKA}

Bernardi, R.A and V. Threadgill. 2010. "Women Directors and Corporate Social Responsibility". Electronic Journal of Business Ethics and Organization Studies. Vol. 15 No. 2, pp. 15-21.

Dharma, N.B.S. and N. Noviari. 2017. "Pengaruh Corporate Social Responsibility dan Capital Intensity Terhadap Tax Avoidance". E-Jurnal Akuntansi Universitas Udayana. Vol. 18 No. 1, Januari: 529-556. ISSN (Online): 23028556. Diakses: 23 Maret 2017.

Femitasari, L. 2014. "Pengaruh Proporsi Dewan Komisaris Independen, Kepemilikan Institusional dan Corporate Social Responsibility Terhadap Agresivitas Pajak". Skripsi. Fakultas Bisnis Universitas Katolik Widya Mandala Surabaya.

Habibi, A.S. 2017. "Pengaruh Corporate Social Responsibility Terhadap Agresivitas 
Pajak". Skripsi. Jurusan Akuntansi Fakultas Ekonomi dan Bisnis Universitas Muhammadiyah Malang.

Handajani, L. 2014. "Pengungkapan Tanggung Jawab Sosial Perusahaan: Determinan, Kinerja Keuangan dan Peran Sumberdaya Tanwujud". Disertasi. Doktor Ilmu Akuntansi Pascasarjana Fakultas Ekonomi dan Bisnis Universitas Brawijaya.

Hidayat, K., A. P. Ompusunggu., H. Suratno. 2016. "Pengaruh Corporate Social Responsibility Terhadap Agresivitas Pajak dengan Insentif Pajak Sebagai Pemoderasi". Jurnal Ilmiah Akuntansi Fakultas Ekonomi. Vol. 2 No. 2. Hal. 39-59.

Hoi, C. K., Q. Wu, and H. Zhang. 2013. "Is Corporate Social Responsibility (CSR) Associated with Tax Avoidance? Evidence from Irresponsible CSR Activities". American Accounting Association. Vol. 88 No. 6, pp. 20252059.

Kusumastuti, S., Supatmi, and P. Sastra. 2006. "Pengaruh Board Diversity terhadap Nilai Perusahaan dalam Perspektif Corporate Governance". Jurnal Ekonomi Akuntansi-Universitas Kristen Petra. Available at: http://puslit.petra.ac.id/journals/account ing. Diakses: 23 Maret 2017.

Lanis, R. and G. Richardson. 2012. "Corporate Social Responsibility and Tax Aggressiveness". Journal of Accounting and Public Policy. Vol. 31 No. hlm: 86-108.

Nugraha, N.B. 2015. "Pengaruh Corporate Social Responsibility, Ukuran Perusahaan, Profitabilitas, Leverage dan Capital Intensity Terhadap Agresivitas Pajak". Skripsi. Jurusan Akuntansi Fakultas Ekonomika dan Bisnis Universitas Diponegoro.
Pradipta, D.H., and Supriyadi. 2015. "Pengaruh Corporate Social Responsibility (CSR), Profitabilitas, Leverage dan Komisaris Independen Terhadap Praktik Penghindaran Pajak". Simposium Nasional Akuntansi 18. Vol, No, hlm.

Pradnyadari, I Dewa A.I. 2015. "Pengaruh Pengungkapan Corporate Social Responsibility Terhadap Agresivitas Pajak". Skripsi. Jurusan Akuntansi Fakultas Ekonomika dan Bisnis Universitas Diponegoro.

Rahindayati, N.M. 2015. "Pengaruh Diversitas Pengurus Pada Luas Pengungkapan Corporate Social Responsibility Perusahaan Sektor Keuangan yang Terdaftar di Bursa Efek Indonesia". Thesis. Megister Akuntansi Universitas Udayana Denpasar.

Rahmawati, A., M.G. Wi Endang, and R.R. Agusti. 2016. "Pengaruh Pengungkapan Corporate Social Responsibility dan Corporate Governance Terhadap Tax Avoidance”. Jurnal Perpajakan (JEJAK). Vol. 10 No. 1.

Ratmono, D. and W.M. Sagala. 2015. "Pengungkapan Corporate Social Responsibility (CSR) Sebagai Sarana Legitimasi: Dampaknya Terhadap Tingkat Agresivitas Pajak". Jurnal Nominal. Vol. 4 No. 2.

Undang-Undang Republik Indonesia No. 40 Tahun 2007 Tentang Perseroan Terbatas

Wahyudi, D. 2015. "Analisis EmpirisPengaruh Aktivitas Corporate Social Responsibility (CSR) Terhadap Prnghindaran Pajak di Indonesia". Jurnal Lingkar Widyaiswara. Vol. 2 No. 4. pp. 05-17. ISSN (Online): 23554118. Diakses: 23 Maret 2017. 